\title{
Comparison of Living Costs by Means of Monetary Minute Currency
}

\author{
Tomas KALA \\ University of Hradec Kralove, Hradec Kralove, Czech Republic \\ tomas.kala@uhk.cz
}

\begin{abstract}
The contribution follows a series of evaluation studies on design of the currency called "Monetary Minute Currency" (in abbreviation MMC or MonMin Currency), and its use for determination and comparison values of several products and commodities in the U.S., and several European markets, which were presented in the HED conferences in the past five years. In the current article, the living costs in Luxemburg, U.S.A., Czech Republic, Paraguay, Nigeria, the Republic of Congo, and Tanzania in 2016 were recalculated into MM\$ and renormalized by the Average Monthly Disposable Salary (Expressed in Monetary Minutes) in each of the countries, respectively. Thus, the comparison of the consumption of the human lifetime (expressed in \%) on the same items of food, beverages, household things, services, entertainment, and others in the above mentioned randomly selected countries could be done and discussed.
\end{abstract}

Keywords: Time, Economic Value, Time-Based Money, Monetary Minute Currency.

\section{Introduction}

The Economy is a wonderful discipline, which is of the utmost importance in all kinds of entrepreneurship, business, social activities of humankind, as well as in the everyday life of people [10-13]. However, Economy has a vexatious Achilles heel in a definition of the Value $[2,6,8,25]$. The role of the Value for evaluation of economic entities and processes in applied economy, entrepreneurship, business, everyday human activities, etc. has been played by money for ages - in its various forms $[9,14,16]$. Values of all of them have been based on negotiation, bargaining, settlement, agreement, market situation, economic, and political power or position of the participants (individual merchants, firms, companies, countries, banks, etc.) [10].

The problem is even augmented by the fact, that modern money systems are prevailingly debt-based (enabling fractional reserve banking) instead of value-based $[12,14,15]$. Further, the amount of money in current economies - and consequently its value - is regulated subjectively by governments and central banks and/or by other monetary authorities on the basis of a declared monetary policy. These two aspects contribute/cause devastating financial crisis time to time [e.g. 1, 3-5, 15]. It is a matter 
of fact, that the modern money is not tied to any "firm" or material background like gold, used to serve for many years in the past.

In my previous works $[10,12]$, I have postulated Time as a Commodity for establishment, measurement, and evaluating a value of economic entities and processes.

In the works [10-12], I have defined a new currency called a "TBM" (for TimeBased Money), as a value of the GDP per capita divided by the number of minutes per year (i.e. 525600) [10]. I have tested the TBM values in the U.S. and the Czech economies, and later on in the Slovak, Polish, and Hungary economies, for a span of 2011-2015 years, too $[12,13]$.

In the antecedent contributions [12, 13], I have focused on the comparison of the living costs and/or incomes evaluated in so-called Monetary Minute currencies (in abbreviation MMC), which were related to the currently used currencies (like in $\$, €$, $£$, and others) via the above mentioned TMB.

In the current article, I have focused on the comparison of consumption of the human lifetime (expressed in \%) on the same items of food, beverages, household things, services, entertainment, and others in randomly selected countries - in Luxemburg, U.S.A., Czech Republic, Paraguay, Nigeria, the Republic of Congo, and Tanzania in 2016.

\section{Methods Used}

This evaluation study is based on the method of qualitative analysis of secondary data and information available on the function of money. I used the data on GDP per capita 2016 related to the Luxemburg, the U.S.A., the Czech Republic, Paraguay, Nigeria, the Republic of Congo, and Tanzania in 2016 from the World Bank [24], and I used values of living costs and incomes in the relevant countries in the year 2016 from NUMBEO [17-23].

I calculated TB \$ values as ratios of the GDP per capita divided by the number of minutes per year (i.e. by 525600) [10] for the Luxemburg, the U.S.A., the Czech Republic, Paraguay, Nigeria, the Republic of Congo, and Tanzania in 2016 (the values of the TB $\$$ are presented in Table 1).

I divided the individual items of the living costs by the relevant TB $\$$ of each of the countries; thus, I obtained the living costs and incomes evaluated in MM\$ (see Table 2 and Figure 1).

I re-normalized the values by the Average Monthly Disposable Salary - Expressed in Monetary Minutes (MM\$) - in each of the countries in 2016, (see Table 3, and 4). In such way, I have received the values of the consumption of the human lifetime (expressed in \%) on the same items of food, beverages, household belongings, services, entertainment, and others, in each of the countries in 2016, respectively. 


\section{$3 \quad$ Results}

In Table 1, there are given values of the GDP per capita and the TB $\$$ in Luxemburg, in the U.S.A., in the Czech Republic, in Paraguay, in Nigeria, in the Republic of Congo, and in Tanzania in 2016.

The individual values of the GDP per capita, and consequently of the TB \$ in individual states differ considerably - more than 100 times between Luxembourg (102,831 US\$ p.c.) and Tanzania (879 US\$ p.c.) - in their GDP nominal values, and more than 200 times in TB $\$$ between Luxembourg (0.19587 US\$ per Minute) and Tanzania (0.00167 US\$ per Minute).

Table 1. Values of the GDP p.c. and the TB\$ in Luxembourg, the U.S.A., the Czech Republic, Paraguay, Nigeria, the Republic of Congo, and Tanzania in 2016 [24].

\begin{tabular}{clrr}
\hline Rank & \multicolumn{1}{c}{ Country } & GDP nominal p.c., in US\$ & TBM in US\$/Minute \\
\hline 1. & Luxembourg & 102.831 & 0.195869 \\
7. & the U.S.A. & 57.467 & 0.109461 \\
35. & the Czech Republic & 18.267 & 0.034794 \\
99. & Paraguay & 4.08 & 0.007771 \\
128. & Nigeria & 2.178 & 0.004149 \\
135. & Republic of Congo & 1.528 & 0.002910 \\
152. & Tanzania & 879 & 0.001674 \\
\hline
\end{tabular}

In Table 2, there is given a list of several food staff costs and also salaries expressed in the Monetary Minutes (MM\$) values in the individual states. The values of individual items of the living costs expressed in MM\$ show large and confused disparities both, in expenditures, and salaries.

However, taking into account the level of allocated Average Monthly Disposable Salary (Net After Tax) expressed in MM\$, the overall picture changes considerably, as it is shown in following Tables 3 , and 4.

In Table 3, there is given the same list of several food staffs prices as that in Table 2 , this time expressed in percentage of the average monthly disposable salaries, in individual countries under the study in 2016.

Table 2. List of Several Food Staffs Prices and Average Monthly Disposable Salaries Expressed in the MM\$ Values in individual countries under study in 2016 [17-23], [24].

\begin{tabular}{|c|c|c|c|c|c|c|c|}
\hline & Luxemburg & $\begin{array}{l}\text { United } \\
\text { States }\end{array}$ & $\begin{array}{l}\text { Czech } \\
\text { Rep. }\end{array}$ & Paraguay & Nigeria & Congo & Tanzania \\
\hline Restaurants & [Min] & [Min] & [Min] & [Min] & [Min] & [Min] & [Min] \\
\hline Meal, Inexpensive Rest. & 105 & 119 & 159 & 515 & 335 & 2938 & 1864 \\
\hline $\begin{array}{l}\text { Meal for } 2 \text { People, Mid- } \\
\text { range Rest., Three-course }\end{array}$ & 421 & 457 & 695 & 2405 & 4008 & 16546 & 15119 \\
\hline McMeal at McDonalds & 52 & 64 & 159 & 619 & 1236 & 4296 & 3996 \\
\hline Domestic Beer(0.5draught) & 30 & 37 & 40 & 126 & 200 & 632 & 800 \\
\hline Imported Beer ( 0.33 bottle) & 24 & 46 & 53 & 218 & 335 & 1031 & 1195 \\
\hline
\end{tabular}




\begin{tabular}{|c|c|c|c|c|c|c|c|}
\hline Coke/Pepsi ( 0.33 bottle) & 16 & 16 & 37 & 112 & 87 & 405 & 293 \\
\hline Water ( 0.33 liter bottle) & 12 & 13 & 28 & 71 & 53 & 296 & 179 \\
\hline \multicolumn{8}{|l|}{ Markets } \\
\hline Milk (regular), (1 liter) & 7 & 8 & 23 & 127 & 374 & 777 & 657 \\
\hline Fresh White Bread (500g) & 11 & 23 & 27 & 56 & 224 & 570 & 358 \\
\hline Rice (white), (1kg) & 13 & 36 & 43 & 84 & 518 & 1292 & 627 \\
\hline Eggs (regular) (12) & 19 & 23 & 47 & 143 & 398 & 907 & 1237 \\
\hline Local Cheese $(1 \mathrm{~kg})$ & 84 & 98 & 237 & 925 & 1562 & 0 & 4755 \\
\hline Chicken Breasts, $(1 \mathrm{~kg})$ & 65 & 78 & 184 & 529 & 805 & 1546 & 2885 \\
\hline Beef Round (1kg) & 105 & 105 & 281 & 768 & 911 & 5625 & 2539 \\
\hline Apples $(1 \mathrm{~kg})$ & 13 & 39 & 36 & 227 & 651 & 1797 & 1756 \\
\hline Banana (1kg) & 11 & 14 & 40 & 92 & 340 & 1103 & 514 \\
\hline Oranges $(1 \mathrm{~kg})$ & 16 & 36 & 44 & 80 & 424 & 1423 & 633 \\
\hline Tomato $(1 \mathrm{~kg})$ & 16 & 36 & 53 & 215 & 441 & 1079 & 538 \\
\hline Potato $(1 \mathrm{~kg})$ & 9 & 23 & 21 & 140 & 415 & 1031 & 460 \\
\hline Onion $(1 \mathrm{~kg})$ & 11 & 23 & 18 & 95 & 275 & 1031 & 526 \\
\hline Water (1.5 liter bottle) & 5 & 16 & 17 & 78 & 108 & 419 & 412 \\
\hline $\begin{array}{l}\text { Bottle of Wine (Mid- } \\
\text { Range) }\end{array}$ & 48 & 110 & 132 & 859 & 803 & 2777 & 4779 \\
\hline Domestic Beer ( 0.5 bottle $)$ & 8 & 19 & 20 & 123 & 200 & 564 & 741 \\
\hline Imported Beer ( 0.33 bottle $)$ & 9 & 25 & 35 & 257 & 393 & 1375 & 962 \\
\hline Pack of Cigarettes (Marlb.) & 35 & 62 & 131 & 230 & 200 & 825 & 848 \\
\hline \multicolumn{8}{|l|}{ Salaries And Financing } \\
\hline $\begin{array}{l}\text { Average Monthly Net } \\
\text { Salary (After Tax) }\end{array}$ & 17944 & 29700 & 29936 & 43567 & 46534 & 156893 & 192354 \\
\hline
\end{tabular}

Table 3. List of several food-staff prices expressed in percentage of the average monthly disposable salaries in individual countries under the study in 2016 [17-23], [24].

\begin{tabular}{|c|c|c|c|c|c|c|c|}
\hline & Luxemburg & United States & Czech Rep. & Paraguay & Nigeria & Congo & Tanzania \\
\hline Restaurants & [\%] & {$[\%]$} & [\%] & {$[\%]$} & {$[\%]$} & {$[\%]$} & [Min] \\
\hline $\begin{array}{l}\text { Meal, } \\
\text { Inexpensive } \\
\text { Rest. }\end{array}$ & 0.58 & 0.40 & 0.53 & 1.18 & 0.72 & 1.87 & 1864 \\
\hline $\begin{array}{l}\text { Meal for } 2 \\
\text { People, Mid- } \\
\text { range Rest., } \\
\text { Three-course }\end{array}$ & 2.35 & 1.54 & 2.32 & 5.52 & 8.61 & 10.55 & 15119 \\
\hline $\begin{array}{l}\text { McMeal at } \\
\text { McDonalds }\end{array}$ & 0.29 & 0.22 & 0.53 & 1.42 & 2.66 & 2.74 & 3996 \\
\hline $\begin{array}{l}\text { DomesticBeer } \\
\text { ( } 0.5 \text { draught })\end{array}$ & 0.17 & 0.12 & 0.13 & 0.29 & 0.43 & 0.40 & 800 \\
\hline $\begin{array}{l}\text { Imported Beer } \\
(0.33 \text { bottle })\end{array}$ & 0.13 & 0.15 & 0.18 & 0.50 & 0.72 & 0.66 & 1195 \\
\hline $\begin{array}{l}\text { Coke/Pepsi } \\
\text { ( } 0.33 \text { bottle) }\end{array}$ & 0.09 & 0.05 & 0.12 & 0.26 & 0.19 & 0.26 & 293 \\
\hline $\begin{array}{l}\text { Water }(0.33 \\
\text { liter bottle) }\end{array}$ & 0.07 & 0.04 & 0.09 & 0.16 & 0.11 & 0.19 & 179 \\
\hline
\end{tabular}


Markets

Milk (regular)

(1 liter)

Fresh White

Bread (500g)

Rice (white),

(1 kg)

Eggs (regular)

(12)

Local Cheese

(1kg)

Chicken

Breasts, $(1 \mathrm{~kg})$

Beef Round

(1 kg)

Apples (1kg)

Banana $(1 \mathrm{~kg})$

Oranges $(1 \mathrm{~kg})$

Tomato $(1 \mathrm{~kg})$

Potato $(1 \mathrm{~kg})$

Onion $(1 \mathrm{~kg})$

Water (1.5

liter bottle)

Bottle of Wine

(Mid-Range)

Domestic Beer

(0.5 bottle)

Imported Beer

( 0.33 bottle)

Pack of

Cigarettes

(Marlb.)

\begin{tabular}{|c|c|c|c|c|c|}
\hline 0.04 & 0.03 & 0.08 & 0.29 & 0.80 & 0.50 \\
\hline 0.06 & 0.08 & 0.09 & 0.13 & 0.48 & 0.36 \\
\hline 0.07 & 0.12 & 0.14 & 0.19 & 1.11 & 0.82 \\
\hline 0.11 & 0.08 & 0.16 & 0.33 & 0.85 & 0.58 \\
\hline 0.47 & 0.33 & 0.79 & 2.12 & 3.36 & 0.00 \\
\hline 0.36 & 0.26 & 0.61 & 1.21 & 1.73 & 0.99 \\
\hline 0.59 & 0.35 & 0.94 & 1.76 & 1.96 & 3.59 \\
\hline 0.07 & 0.13 & 0.12 & 0.52 & 1.40 & 1.15 \\
\hline 0.06 & 0.05 & 0.13 & 0.21 & 0.73 & 0.70 \\
\hline 0.09 & 0.12 & 0.15 & 0.18 & 0.91 & 0.91 \\
\hline 0.09 & 0.12 & 0.18 & 0.49 & 0.95 & 0.69 \\
\hline 0.05 & 0.08 & 0.07 & 0.32 & 0.89 & 0.66 \\
\hline 0.06 & 0.08 & 0.06 & 0.22 & 0.59 & 0.66 \\
\hline 0.03 & 0.05 & 0.06 & 0.18 & 0.23 & 0.27 \\
\hline 0.27 & 0.37 & 0.44 & 1.97 & 1.72 & 1.77 \\
\hline 0.05 & 0.06 & 0.07 & 0.28 & 0.43 & 0.36 \\
\hline 0.05 & 0.09 & 0.12 & 0.59 & 0.84 & 0.88 \\
\hline 0.19 & 0.21 & 0.44 & 0.53 & 0.43 & 0.53 \\
\hline
\end{tabular}

It is obvious from the Table 3, that the relative prices (in \% of the average monthly disposable salaries) of meals and drinks in restaurants, as well as the relative prices of meals and drinks in the corresponding markets were in the range of units of \% (with exception of the three-course meal in restaurant in the Republic of Congo, which price was higher than $10 \%$ ), while most of the items in Paraguay, Nigeria, the Republic of Congo and Tanzania were several times higher than in the United States, Luxembourg, and in the Czech Republic.

In Table 4, there is given the list of relative Transportation, Utilities, Sport and Leisure Child Care, Clothing and Shoes, Rental per Month, and Buy Apartment relative prices expressed in percentage of the average monthly disposable salaries in individual countries under the study in 2016. 
Table 4. Relative Transportation, Utilities, Sport and Leisure, Child Care, Clothing and Shoes, Rental per Month, and Buy Apartment prices to a percentage of the average monthly disposable salaries in individual countries under the study in 2016 [17-23], [24].

\begin{tabular}{|c|c|c|c|c|c|c|c|}
\hline & Luxemburg & $\begin{array}{l}\text { United } \\
\text { States }\end{array}$ & Czech Rep. & Paraguay & Nigeria & Congo & Tanzania \\
\hline \multicolumn{8}{|l|}{ Transportation } \\
\hline One-way Ticket & 0.07 & 0.07 & 0.11 & 0.12 & 0.22 & 0.11 & 0.06 \\
\hline Monthly Pass & 1.51 & 2.00 & 2.30 & 7.62 & 21.17 & 19.71 & 10.39 \\
\hline Taxi Start (Normal Tariff) & 0.09 & 0.09 & 0.18 & 0.26 & 0.57 & 0.36 & 0.69 \\
\hline Taxi $1 \mathrm{~km}$ (Normal Tariff) & 0.10 & 0.05 & 0.11 & 0.53 & 0.28 & 0.35 & 0.42 \\
\hline Taxi 1hour Waiting & 1.01 & 0.83 & 1.33 & 3.15 & 1.43 & 1.83 & 1.39 \\
\hline Gasoline (1 liter) & 0.04 & 0.02 & 0.13 & 0.00 & 0.21 & 0.26 & 0.29 \\
\hline Volkswagen Golf1.4 90KW & 704.23 & 673.65 & 1827.12 & 4230.48 & 4305.98 & 6570.88 & 8729.41 \\
\hline Toyota Corolla 1.61 97kW & 806.32 & 621.11 & 1901.41 & 6901.91 & 6688.62 & 4868.23 & 3133.34 \\
\hline \multicolumn{8}{|l|}{ Utilities (Monthly) } \\
\hline $\begin{array}{l}\text { Basic (Electricity, Heating, } \\
\text { Cooling, Water, Garbage) for } \\
\text { 85m2 Apartment }\end{array}$ & 7.42 & 4.54 & 17.41 & 21.73 & 18.30 & 27.49 & 20.92 \\
\hline $\begin{array}{l}1 \text { min. of Prepaid Mobile } \\
\text { Tariff Local }\end{array}$ & 0.00 & 0.00 & 0.01 & 0.04 & 0.05 & 0.03 & 0.04 \\
\hline $\begin{array}{l}\text { Internet (60 Mbps or More, } \\
\text { Unlimited Data, } \\
\text { Cable/ADSL) } \\
\text { Sports and Leisure }\end{array}$ & 1.43 & 1.74 & 1.79 & 12.21 & 28.80 & 65.71 & 41.21 \\
\hline $\begin{array}{l}\text { Fitness Club, Monthly Fee for } \\
1 \text { Adult }\end{array}$ & 1.83 & 1.11 & 3.28 & 7.36 & 16.38 & 24.82 & 22.35 \\
\hline $\begin{array}{l}\text { Tennis Court Rent ( } 1 \text { Hour on } \\
\text { Weekend) }\end{array}$ & 0.75 & 0.47 & 1.05 & 2.93 & 2.87 & 5.84 & 2.71 \\
\hline Cinema, , 1 Seat & 0.30 & 0.34 & 0.71 & 1.84 & 2.15 & 3.50 & 1.40 \\
\hline \multicolumn{8}{|l|}{ Childcare } \\
\hline $\begin{array}{l}\text { Preschool/Kindergarten, } \\
\text { Private, Monthly } 1 \text { Child }\end{array}$ & 35.68 & 25.98 & 39.29 & 20.36 & 47.94 & 65.71 & 107.77 \\
\hline $\begin{array}{l}\text { International Primary School, } \\
\text { Yearly } 1 \text { Child } \\
\text { Clothing and Shoes }\end{array}$ & 503.09 & 553.68 & 658.60 & 662.20 & 1498.48 & 0.00 & 0.00 \\
\hline 1 Pair of Jeans (Levis 501) & 2.54 & 1.28 & 6.95 & 18.59 & 10.55 & 12.37 & 10.30 \\
\hline $\begin{array}{l}1 \text { Summer Dress in a Chain } \\
\text { Store (Zara, H\&M, ...) }\end{array}$ & 1.34 & 1.06 & 3.30 & 11.86 & 14.71 & 14.24 & 16.82 \\
\hline $\begin{array}{l}1 \text { Pair of Nike Running Shoes } \\
\text { (Mid-Range) }\end{array}$ & 3.02 & 2.26 & 7.63 & 21.55 & 21.02 & 36.51 & 17.31 \\
\hline $\begin{array}{l}1 \text { Pair of Men Leather } \\
\text { Business Shoes } \\
\text { Rental per Month }\end{array}$ & 4.30 & 2.82 & 9.06 & 15.68 & 27.39 & 27.38 & 20.57 \\
\hline $\begin{array}{l}\text { Apartment ( } 1 \text { bedroom }) \text { in } \\
\text { City Centre }\end{array}$ & 46.10 & 36.64 & 52.75 & 73.58 & 260.27 & 219.03 & 120.82 \\
\hline $\begin{array}{l}\text { Apartment ( } 1 \text { bedroom }) \\
\text { Outside of Centre }\end{array}$ & 37.07 & 28.68 & 40.93 & 58.18 & 116.93 & 80.31 & 84.75 \\
\hline $\begin{array}{l}\text { Apartment ( } 3 \text { bedrooms) in } \\
\text { City Centre }\end{array}$ & 89.21 & 58.76 & 87.30 & 159.79 & 511.18 & 763.09 & 358.13 \\
\hline $\begin{array}{l}\text { Apartment ( } 3 \text { bedrooms) } \\
\text { Outside of Centre } \\
\text { Buy Apartment Price }\end{array}$ & 63.10 & 45.54 & 60.28 & 119.70 & 278.10 & 244.59 & 304.34 \\
\hline $\begin{array}{l}\text { Price per Square Meter to } \\
\text { Buy Apartment in City Centre }\end{array}$ & 260.28 & 69.39 & 297.11 & 223.35 & 478.44 & 1886.09 & 372.64 \\
\hline
\end{tabular}


It can be deduced from the figures listed in the Table 4, that:

- the relative prices (in \%) of Transportation, Utilities, and Sport and Leisure were relatively low - from zero to tenths percentage of the average monthly disposable salaries in all of the countries studied. Just relative prices for Monthly Pass, Basic Utilities, and Internet were somewhat higher in Paraguay, Nigeria, Republic of Congo and Tanzania than in the United States, and in Luxembourg.

- The relative prices of cars are many times greater than the average monthly disposable salaries expressed in MM\$ in individual countries under the study in 2016. The lowest relative prices were found in the U.S.A. (673.65\%, and $621.11 \%$, respectively for Volkswagen Golf, and for Toyota Corolla). The highest relative price of Volkswagen Golf - 8729.41 \% - was found in Tanzania, and for Toyota Corolla $-6688.62 \%$ in Nigeria, which seem to be very high to afford the cars by people with average incomes.

- The Pre-School Private 1 Child Care per Month were found as high as tens percent of the average monthly disposable salaries in most of the countries studied (in Tanzania it was nearly 108\%), and they were somewhat higher in Nigeria, the Republic of Congo and Tanzania than in the United States, Luxembourg, the Czech Republic, and in Paraguay.

- The relative prices of the International Primary School for 1 Child per Year were found more than five (in Nigeria nearly fifteen) times higher than were the average monthly disposable salaries in the individual countries studied.

- The relative prices (in \%) of the Clothing and Shoes were from units up to tens of a percentage of the average monthly disposable salaries in all of the countries studied. They were higher in Paraguay, Nigeria, the Republic of Congo and Tanzania than in the United States, Luxembourg, and in the Czech Republic,

- The relative prices (in \%) of the of the Rental per Month were as high as tens (in the United States, Luxembourg, and in the Czech Republic) up to several hundred percent of the average monthly disposable salaries - Paraguay, Nigeria, Republic of Congo and Tanzania. It means, that people with average monthly incomes cannot afford to rent apartments in the Cities in those countries,

- The prices per Square Meter to Buy in the U.S.A. were only several ten percent, meanwhile the prices per Square Meter to Buy in Luxembourg, the Czech Republic, Paraguay, and Tanzania were comparable in hundreds of Percent.

- Very high relative prices per Square Meter to Buy were found in the Republic of Congo, reaching more than $1800 \%$ per Square Meter to Buy of the average monthly disposable salaries, in this country under the study in 2016. It means, that people with average monthly incomes can hardly afford to buy apartments this country at all. 
This evaluation study is a part of testing the idea of using Time as a prospective base/commodity for a new money system, which would be objective, predictable, dynamically evolving, and readily introduced in the economy, business and everyday life [10-13].

In my previous works, I defined and tested so called Monetary Minute Currencies (in abbreviation MMC), consequently to my former work [12], in which I defined socalled Time-Based Money ("TBM") as a value of the GDP per capita divided by the number of minutes per year (i.e. 525600). The MMC were related to the currently utilized currencies (like in $\$, €, £$, and others) via the mentioned TMB.

In this study, I have randomly selected several countries from the "List of per capita nominal GDP for countries" of the World Bank [24] from different positions. Namely, Luxembourg which took the $1^{\text {st }}$ position in the "List ..", the U.S.A.- the $7^{\text {th }}$ position, , the Czech Republic $-35^{\text {th }}$ position, Paraguay $-99^{\text {th }}$ position, Nigeria $-128^{\text {th }}$ position, the Republic of Congo $-135^{\text {th }}$ position, and Tanzania, which took a $152^{\text {nd }}$ position in the World (see Table 1).

Then, I have calculated the TB\$ (in Minutes) for the individual countries (by dividing corresponding values of the GDP per capita with the number of minutes per year (i.e. 525600). As expected, the value of the TB $\$$ corresponding to the individual countries studied differed considerably (see Table 1).

In the second step, I divided values from the "Costs of Living" - published by the NUMBEO [17-23] for the countries under discussion - by corresponding values of the TB\$. Thus, I have received the List of Several Food Staffs Prices and Average Monthly Disposable Salaries Expressed in the MM\$ Values in individual countries under the study in 2016 (see Table 2). The values of individual items of the living costs expressed in MM\$ showed large, confused disparities both, in expenditures, and salaries.

That is why I divided the individual items of costs in Table 2 by corresponding values of the Average Monthly Disposable Salary (Net After Tax) expressed in MM\$. In this way, I received an overview of the costs/prices of living expressed in percentage of the average monthly disposable salaries, in individual countries under the study in 2016 (see Tables 3, and 4). In other words, I received the values of the consumption of the human lifetime (expressed in \% of the average monthly disposable salaries) on the same items of food, beverages, household belongings, services, entertainment, and others, in the individual countries in 2016, respectively.

Surprisingly, the found prices of "standard level" food-staff and products expressed in a percentage of the average monthly disposable salaries, in individual countries under the study in 2016 did not differ so significantly as the "high level" products, goods and services, and housing (see Table 4).

They can reveal not just the differences in prices of selected food staffs and products, services, etc. but also the differences in affordability of the products taking into account the average monthly disposable salaries in different countries on the "homologized" Monetary Minute base. 
The results of the current study show, that MM\$ can serve for comparison of values/costs/prices of the same/similar products or - generally - all economic entities expressed in different currencies, and to reveal disparities among them [10-13].

However, the whole picture, namely the affordability of the food-staff products, goods, services, etc. should be interpreted with caution - in relation with number of family member dependent on disposable salaries, unemployment rate, and the general social situation in specific countries.

The quantitative accuracy and reliability of the results given in the study are limited by the accuracy and reliability of the figures available and the time of its creation.

In the former work was found [12], that the current nominal value of a specific economic entity expressed in Monetary Minutes, i.e. MM\$, MM£, MM€, etc. differs in relation on which current money currency system - USD, GBP, EUR, etc. - is used, respectively. From this point of view, the comparison would be better done on the base of GDP, p.c. expressed in corresponding currencies of individual countries studied. It is, not in the U.S. Dollars only, as the situation can be influenced by exchange ratios policies, and also by the access policies the international markets. However, there was found lack of reliable data on GDP, number of population, unemployment, currency ratio policies, etc. pertinent to individual countries.

Nevertheless, the quality of the fundamental finding, i.e.: the currency MonMin can serve as a useful and practical tool for the Value determination, and for measurement of any economic entities (either elements and/or processes) is undeniable.

Taking into account the results of this and my previous works [10-13], I dare state that the TBM and MMC are prospective tools for tracing, measuring, and analyzing wide spectrum of value transformations in the real economy, including production costs/efficiency diversities in different countries or regions, and different historical eras in a more objective way, than the current spectrum of currencies worldwide enable.

(Note: I do not insist on the only term/name/title "MMc" for the currency called "Monetary Minute Currency". The abbreviations such as TMc (for the "Time Money Currency") could be better for practical use especially, when relating to the specific traditionally used money (like "Time Money Dollar" - TM\$ or "Time Dollar" - T\$, "Time Money Pond" - TM£ or "Time Pound"- T£, "Time Money EUR" - TME or "Time EUR" - TE, etc.).

Acknowledgements. The author of the contribution is obliged to express deep thanks to Prof. Ing. Ladislav Hájek, CSc. form the Faculty of Informatics and Management of the University of Hradec Kralove for his valuable discussions and advice which considerably improved the quality of the contribution.

\section{References}

1. Abel, A., Bernanke, B.: Fractional-reserve banking "14". In: Macroeconomics (5th ed.). Pearson. pp. 522-532. (2005).

2. Acemoglu, D.; Robinson, J. A.: Why Nations Fail: The Origins of Power, Prosperity, and Poverty. Crown Business division of Random House (2012). 
3. Angelides Commission: Conclusion of the Financial Crisis Inquiry Commission, (2011), http://web.archive.org/web/20110304020317/http://c0182732.cdn1.cloudfiles.rackspaceclo ud.com/fcic_final_report_conclusions.pdf, last accessed 2018/11/15.

4. Bernanke, B.S.: Four Questions about the Financial Crisis, Lecture at Morehouse College, Atlanta, Georgia, Board of Governors of the Federal Reserve System, 14. April, (2009), http://www.federalreserve.gov/newsevents/speech/bernanke20090414a.htm, last accessed 2018/11/15.

5. Classens, S. and Kose, M.A.: Financial Crises: Explanations, Types, and Implications, IMF Working Paper WP/13/28, International Monetary Fund (2013), http://www.imf.org/external/pubs/ft/wp/2013/wp1328.pdf., last accessed 2018/11/15.

6. Collom, E., Kyriacou, C., Lasker, J. Equal Time, Equal Value: Community Currencies and Time Banking in the US. Routledge, New York (2016).

7. D-Statis: Statistisches Bundesamt, 2016, https://www.destatis.de/EN/FactsFigures/NationalEconomyEnvironment/NationalAccount s/DomesticProduct/Tables/Q_GDP.html, last accessed 2017/03/30.

8. George H., Davis, L.: Chapter 8 - Economic Value - Its Real Meaning and Final Measure. $\mathrm{http} / / / \mathrm{www}$.politicaleconomy.org/speII 8.htm, last accessed 2017/03/30.

9. Friedman, M.: Money, Encyclopaedia Britannica, https://www.britannica.com/topic/money, last accessed 2017/06/27.

10. Kala, T.: Management \& Financial and Economic Crisis 2007-2008, In: Jedlička, P. (ed.) Conference on Economic Development and Management of Regions, Hradec Economic Days (HED) 2014, Hradec Kralove 2014, Gaudeamus Hradec Kralove, pp. 415-421. (2014).

11. Kala, T.: Time-Based Money System: Its Use in the U.S.A. and the Czech Economies, 2016 Advancement on Informatics, Business and Management International Conference (ADIBUM), September 20 - 22, 2016, University of Hradec Kralove, Czech Republic, Journal of Engineering and Applied Sciences (Medwell Journals) Special Issue. ISSN 1816949x (Print) ISSN 1818-7803 (in Print).

12. Kala, T.: Time-Based Money in V4 Economies, In: Jedlička, P., Soukal, I., Maresova, P. (eds.), Hradecké ekonomické dny Roč. 7(1) Recenzovaný sborník mezinárodní odborné konference Hradecké ekonomické dny 2017 Hradec Králové 31. ledna a 1. února 2017, Hradec Kralove, pp. 73-78. (2017).

13. Kala, T.: Monetary Minute Currency - An Economic Value Setting Tool, In: Jedlička, P., Soukal, I., Maresova, P. (eds.), Hradec Economic Days Vol. 8(1) Double-blind peerreviewed proceedings part I. of the international scientific conference Hradec Economic Days 2018, pp. 377-387. (2018).

14. Kortsch, U.: Proposed Monetary Plan for the US. In Monetary Plan Overview, Monetary Trust Initiative, https://wiki.p2pfoundation.net/Monetary_Trust_Initiative, last accessed 2017/06/28

15. Mishkin, F.S.: The Economics of Money. In: Banking, and Financial Markets (Alternate Edition), Boston, Addison Wesley (2007).

16. Ng, S. and Wright, J.H.: Facts and Challenges from the Great Recession for Forecasting and Macroeconomic Modeling, Journal of Economic Literature 51(4), pp. 1120-1154. DOI: 10.1257/jel.51.4.1120.

17. NUMBEO: Costs of Living, https://www.numbeo.com/cost-ofliving/country_result.jsp?country=Luxembourg\&displayCurrency=USD, last accessed 2017/12/08

18. NUMBEO: Costs of Living, https://www.numbeo.com/cost-of-living/country_result.jsp?country=United+ States, last accessed 2017/12/08. 
19. NUMBEO: Costs of Living, https://www.numbeo.com/cost-of-living/country_result.jsp?country=Czech+ Republic\&displayCurrency=USD, last accessed 2017/12/08.

20. NUMBEO: Costs of Living, https://www.numbeo.com/cost-of-living/country_result.jsp?country=Paraguay, accessed 2017/12/08

21. NUMBEO: Costs of Living, https://www.numbeo.com/cost-of-living/country_result.jsp?country=Nigeria \&displayCurrency=USD, last accessed 2017/12/08.

22. NUMBEO: Costs of Living,

23. https://www.numbeo.com/cost-of-living/country_result.jsp?country=Congo, last accessed 2017/12/08

24. NUMBEO: Costs of Living, https://www.numbeo.com/cost-ofliving/country_result.jsp?country=Tanzania\&displayCurrency=USD, last accessed 2017/12/08

25. World Bank: International Comparison Program database, http://data.worldbank.org/indicator/NY.GDP.PCAP.PP.CD?order=wbapi_data_value_201 4+wbapi_data_value+wbapi_data_value-last\&sort=desc, last accessed 2017/12/04.

26. Wolff, R. D., Bruce B. Callari, R., Callari, A.:

Marx's (not Ricardo's) 'Transformation Problem: A Radical Reconceptualization, History of Political Economy, 14(4): 564-582, (1982) DOI:10.1215/00182702-14-4-564. 